\title{
Microencapsulated Bovine Chromaffin Cells In Vitro: Effect of Density and Coseeding with a NGF-Releasing Cell Line
}

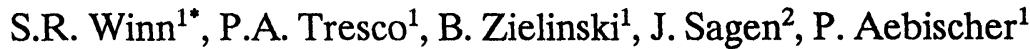 \\ ${ }^{1}$ Artificial Organ Laboratory, Brown University, Providence, RI 02912, ${ }^{2}$ Department of Anatomy \& Cell \\ Biology, University of Illinois, IL 60612, USA
}

"Current address: Cytotherapeutics Inc., 4 Richmond Sq., Providence, RI 02906, USA

\begin{abstract}
Immobilization of discrete cell clusters within a partially crosslinked matrix prevents reaggregation of primary tissues and may provide a means for long-term maintenance of encapsulated cells. Dissociated bovine adrenal chromaffin (BAC) cells were suspended throughout crosslinked polyanionic microspheres previously shown to be selectively permeable. Microcapsules approximately $\mathbf{5 0 0}$ $\mu \mathrm{m}$ in diameter were seeded with: 1) three different densities of BAC cells; and 2) BAC cells suspended in Matrigel ${ }^{\circledR}$ or coseeded with a genetically modified nerve growth factor (NGF)releasing fibroblast cell line. Each group was analyzed in vitro at 1,4 and 8 weeks for spontaneous and potassium-evoked release of catecholamines, and maintained in vitro for up to 12 weeks for morphological observations. Over time, release of norepinephrine (NE) and epinephrine (EPI) diminished, while dopamine (DA) remained constant from the monoseeded capsules. In the coseeded group, an increase in potassium-evoked release of $\mathrm{DA}$ was observed from 1 to 4 weeks, and remained at that level up to 8 weeks. Encapsulated chromaffin cells retained a rounded morphology typical of undifferentiated cells. Intact chromaffin cells with well preserved and abundant secretory
\end{abstract}

Reprint address:

Dr. Patrick Aebischer

Artificial Organ Laboratory

Box G-393

Brown University

Providence, RI 02912, USA granules were observed ultrastructurally after 4 weeks in vitro. Small neurites from the chromaffin cells in the coseeded group were observed at 4 weeks with light microscopy, and up to 12 weeks with electron microscopy. Under static incubation conditions, $1 \mathrm{mM}$ D-amphetamine resulted in a significant increase in the output of $\mathrm{NE}$ and DA from the coseeded capsules 8 weeks postimplantation, as compared to microcapsules loaded with chromaffin cells alone. Encapsulation within an immobilization matrix allows manipulation of the internal environment, thereby providing the ability to pre-treat cells with various factors in a non-invasive manner, which may enhance long-term cellular viability.

\section{KEY WORDS}

chromaffin, microcapsules, catecholamines, NGF, fibroblasts, engineered

\section{INTRODUCTION}

Neural implantation of polymer-encapsulated tissues has been utilized as a model system for analyzing the effectiveness of diffusive release of neuroactive agents in denervated regions of the central nervous system $/ 1,26,32 /$. In animal models of parkinsonism, transplantation of encapsulated PC12 cells $/ 26,32 /$ and bovine adrenal chromaffin (BAC) cells $/ 1 /$ to a denervated striatum has been reported to alleviate dopamine receptor agonist-induced rotational asymmetry in rats. In the $\mathrm{PC} 12$ cell implants, the effects appeared to be dopamine mediated, since extracellular dopamine 
measured by microdialysis approached control levels /26/. However, with adrenal medullary transplants, factors other than catecholamine release may be responsible for the behavioral improvements $/ 2,3,5 /$. Trophic mechanisms are currently the most widely discussed possibilities $/ 2,3,5,7,18 /$.

When adrenal chromaffin cells are isolated from the glucocorticoid-releasing cortical cells, differentiation of the chromaffin cells into a neuronal phenotype can occur both in vitro /27$29 /$ and in oculo /14,15,24/. Extensive neuritic outgrowths from chromaffin cells are dependent on the presence of differentiating factors, such as NGF, when maintained in culture $/ 13,25,29 /$. Both adrenal medulla $/ 6,9,15,22 /$ and dissociated chromaffin cell $/ 3,4,17 /$ grafts show poor survival when transplanted into striatal parenchyma. However, NGF infused into the region of the adrenal medullary cell transplants has been reported to enhance survival, induce neuritic extensions, and increase the effectiveness of behavioral recovery $/ 23 /$. This raises the question of whether low concentrations of NGF in a lesioned striatum $/ 11 /$ contribute to the inability of the chromaffin cells to maintain a neuronal phenotype which may then limit their survival, or are other factors contributing to poor intrastriatal viability? The ability to deliver a chronic supply of NGF to chromaffin cells from a living system may improve graft survival and avoid the problems and limitations inherent in pumps or polymer systems $/ 30 /$.

In the present study, polyelectrolyte-based microspheres containing either dissociated BAC cells or chromaffin cells coseeded with an NGFreleasing cell type, were maintained and characterized in vitro for: 1) catecholaminerelease for up to 8 weeks; and 2) morphology for up to 12 weeks. Polyelectrolytes are water-based ionic polymers in which a selectively permeable membrane is formed by interfacial adsorption of a polycation on spherical polyanionic crosslinked matrices $/ 8,12 /$. The technique described in this report immobilizes and maintains discrete cell clusters over extended periods of time in a transparent three-dimensional matrix. Furthermore, microencapsulation provides a method for pre-treating chromaffin cells with differentiating factors prior to transplantation studies without adding the insult of manipulating differentiated cultured chromaffin cells off a two-dimensional substrate.

\section{MATERIALS AND METHODS}

\section{Cellular preparations}

Dissociated BAC cells were isolated as previously described $/ 19,20 /$ and maintained in DMEM supplemented with $6 \%$ fetal calf serum (Gibco, Grand Island Biological Co., Grand Island, $\mathrm{NY}$ ) at $37^{\circ} \mathrm{C}$ in a water-saturated, ambient air atmosphere containing $5 \% \mathrm{CO}_{2}$. Approximately one week following the isolation procedure, cells were harvested by aspiration, the supernatant was collected and centrifuged at $800 \mathrm{~g}$. The fibroblast cell line R208F was genetically modified through infection with a retroviral vector containing the mouse NGF cDNA /21/. The clonal line designated R208N.8 was maintained in DMEM supplemented with $10 \%$ fetal calf serum and utilized for coseeding with BAC cells after removal from tissue culture flasks by trypsin-EDTA treatment. These cells were a generous gift from Drs. Xandra Breakefield and Priscilla Short, Massachusetts General Hospital. The R208N.8 NGF releasing clonal cell line was previously assayed by ELISA and the measured release of NGF was $165 \mathrm{pg} / 10^{5}$ cells/hour (P. Short, personal communication). The biological activity of the NGF released from the R208N.8 cells was assessed by placing R208N.8 cell-loaded microcapsules in wells containing cultured PC12 cells. Induction of neurites from PC12 cells that were at least twice the length of a cell body's diameter was required for a positive NGF effect.

\section{Encapsulation procedure}

BAC cells in $250 \mu \mathrm{l}$ DMEM were suspended in $750 \mu \mathrm{l}$ of a $2 \%(\mathrm{w} / \mathrm{v})$ isotonic sodium alginate (KelcoGel HV, Kelco, NJ) at a density of 2, 5, and $10 \times 10^{6} / 250 \mu \mathrm{l}$, designated low, medium and high, respectively. In every condition the temperature was maintained at or near $10^{\circ} \mathrm{C}$. The coseeded conditions, $2 \times 10^{6}$ R208N.8 cells and $3 \times 10^{6}$ chromaffin cells mixed in $250 \mu \mathrm{l}$ 
Matrigel ${ }^{\circledR}$ (Collaborative Research, Lexington, MA) were suspended in $750 \mu \mathrm{l} 2 \%$ isotonic sodium alginate. The control for the coseeded group, $4 \times 10^{6}$ chromaffin cells mixed in $250 \mu \mathrm{l}$ Matrige ${ }^{\oplus}$, was also suspended in $750 \mu 1$ isotonic sodium alginate. Matrigel ${ }^{\circledR}$, an extracellular matrix hydrogel containing predominantly laminin $(7 \mathrm{mg} / \mathrm{ml})$ and type IV collagen $(0.25$ $\mathrm{mg} / \mathrm{ml}$ ), is a liquid under approximately $4-25^{\circ} \mathrm{C}$ conditions that was utilized as a substratum for the fibroblasts. The cell-loaded microcapsules were fabricated as previously described $/ 1 /$. Approximately 200 cell-loaded microcapsules were placed in individual wells of a 24 multiwell tissue culture plate (Falcon 3047). Catecholamine analysis was performed at 1,4 , and 8 weeks on cell-loaded microcapsules maintained in vitro. The diameters of 20 microcapsules from each group were measured with a morphometric analysis system (CUE-2, Olympus Corp., Lake Success, NY).

\section{In vitro release kinetics}

Basal and potassium-evoked catecholamine release profiles under static conditions were determined by high performance liquid chromatography (HPLC) with an electrochemical detector (LCEC). Both basal (5.4 mM $\mathrm{K}^{+}$) and potassium-evoked $\left(56 \mathrm{mM} \mathrm{K}^{+}\right)$release was measured by analyzing $450 \mu \mathrm{l}$ HBSS, supplemented with $0.29 \mathrm{mM}$ ascorbate, incubated for $15 \mathrm{~min}$ each, then treated with $50 \mu \mathrm{l}$ of $1.1 \mathrm{~N} \mathrm{HClO}_{4}$ prior to column injection. The medium density chromaffin cell-loaded microcapsules and the coseeded microcapsules were also challenged with $1 \mathrm{mM}$ D-amphetamine sulfate in HBSS under the same conditions after being maintained for 4 and 8 weeks in vitro. The same wells from each group were repeatedly stimulated over time. The HPLC system and the catecholamine detection limit of the chromatographic system used have been previously described $/ 1 /$.

Catecholamine release was expressed as either the average release/well in ng/15 min or as per capsule (pg/capsule/15 min) obtained by dividing total catecholamine release by the number of microcapsules/well.

\section{Morphologic analysis}

Following 1, 4, 8 and 12 week maintenance periods in vitro, microcapsules were fixed in a $3 \%$ paraformaldehyde, $0.5 \%$ glutaraldehyde solution, rinsed in phosphate buffered saline (PBS), and dehydrated up to $95 \%$ ethanol. A 1:1 solution of $95 \%$ ethanol and the infiltration solution of glycol methacrylate (Historesin, Reichert-Jung for Cambridge Instruments) was next added to the specimens for 1 hour. Pure infiltration solution replaced the 1:1 mixture and remained for at least 2 hours. The specimens were briefly rinsed with the embedding solution, transferred to flat molds, and embedded in glycol methacrylate. Sections $5 \mu \mathrm{m}$ thick were sectioned (Reichert-Jung, Supercut microtome 2050), mounted on glass slides and stained for Nissl substance with cresyl violet. After 4 and 8 weeks in vitro, the relationship and pattern of viability in the medium density chromaffin cellloaded microcapsules was visualized by simultaneous staining with fluorescein diacetate (FDA) and propidium iodide (PI). One $\mathrm{ml}$ suspensions from each time period with approximately 50 cell-loaded microspheres were exposed to working solutions as previously described /10/. An average of 10 microcapsules/ time period were evaluated first for PI, which labels nonviable cells, and secondly with FDA, labeling viable cells, using an epifluorescent microscope (Zeiss IM 35). For ultrastructural observations, microcapsules were fixed in $3 \%$ paraformaldehyde and $2 \%$ glutaraldehyde overnight, rinsed in $50 \mathrm{mM}$ PBS and processed as previously described $/ 31 /$. Ultrathin sections were stained with Reynold's lead citrate and uranyl acetate and analyzed with a Philips 410 transmission electron microscope.

\section{Statistical analysis}

Mean and standard errors of the mean (S.E.M.) were calculated for each time point and group, with the exception of the size distribution of the cell-loaded microcapsules. Student's paired t-test was used for statistical analysis. 


\section{RESULTS}

\section{Bioassay}

The NGF released from R208N.8 cell-loaded microcapsules was shown to be biologically active by its ability to induce neuritic extensions in cultured $\mathrm{PC} 12$ cells after being cocultured for 5 days in vitro (Fig. 1).

\section{General observations}

There was no significant difference in the average diameters of microcapsules loaded with low, medium and high densities of chromaffin cells $(498 \pm 35 \mu \mathrm{m}, 512 \pm 30 \mu \mathrm{m}$, and $515 \pm 37$ $\mu \mathrm{m}, \pm$ S.D., respectively). The microcapsules contained an average of 250 cells/capsule at low density, 750 at the medium density, and 1500 at the highest density analyzed, which was determined by dividing the total number of cells suspended in alginate by the number of microcapsules fabricated. The Matrigel ${ }^{\circledR}$-containing mono- and coseeded microspheres measured $505 \pm 40$ and $514 \pm 48 \mu \mathrm{m}$ in diameter, respectively. The monoseeded microcapsules contained an average of 600 chromaffin cells, while the coseeded group had 450 chromaffin cells and 200 R208N.8 fibroblasts/capsule.

\section{Catecholamine release}

1. Monoseeded microcapsules: Figure 2 shows the average basal and potassium-evoked release of catecholamines from three wells/group (low, medium and high) in which each group contained approximately 200 capsules/well. One week following the encapsulation procedure, norepinephrine (NE), epinephrine (EPI), and dopamine (DA) were spontaneously released in $5.4 \mathrm{mM}$ HBSS from each group (Fig. 2). Following a $56 \mathrm{mM} \mathrm{K}^{+}$incubation, a significant increase in the output of NE, EPI and DA was observed within each group. In the high and medium density microcapsules, a greater decrease in EPI and NE released was observed from 1 to 4 weeks, with the most significant decline occurring with EPI release from the high density microcapsule group (Fig. 2A). A small decrease in potassium-evoked release of $D^{\prime} i$ was observed from the high and medium density groups, whereas no such decrease over time was seen in the low density group (Fig. 2C). At the low seeding density, the chromaffin cells appeared to release, under basal conditions, a greater proportion of catecholamines compared to $56 \mathrm{mM} \mathrm{K}^{+}$. The medium density chromaffin microcapsules were also analyzed for $15 \mathrm{~min}$, with $1 \mathrm{mM}$ amphetamine. No significant changes in the release characteristics were observed between the basal and amphetamine conditions after 8 weeks in vitro (Fig. 3A). The monoseeded chromaffin cells suspended in Matrige ${ }^{\circledR}$ showed a potassium-evoked catecholamine release pattern similar to that observed in the medium density described previously (Fig. 4A).

2. Coseeded microcapsules: When compared to the capsules containing chromaffin cells in Matrigel ${ }^{\circledR}$ (Fig. 4A), the potassium-evoked catecholamine release profile from approximately 300 coseeded microcapsules/well appeared very similar after 1 week in vitro (Fig. 4B). The quantities of NE/well measured over time decreased similarly to that in the monoseeded microcapsules. In contrast to the Matrige ${ }^{{ }^{\circledR}}$-containing chromaffin microcapsules (Fig. 4A), a sharp decrease in the EPI output was observed with the coseeded capsules at 4 weeks (Fig. 4B). By 8 weeks, EPI was detected in only 2 of the 4 wells stimulated with $56 \mathrm{mM} \mathrm{K}^{+}$. A significant increase in the quantity of dopamine released was observed from 1 to 4 weeks in the coseeded capsules and remained at that elevated level up to 8 weeks in vitro (Fig. 4B). Under static incubation conditions, treatment with $1 \mathrm{mM}$ D-amphetamine induced a significant increase in the output of $\mathrm{NE}$ and DA, as compared to basal levels after 8 weeks of maintenance in vitro (Fig. 3B).

\section{Morphology}

Discrete clusters of chromaffin cells were observed throughout each capsule following the fabrication process (Fig. 5A). These clusters retained their rounded endocrine-like shape and did not reaggregate to form large clusters over time (Fig. 5B). The viability of the medium density chromaffin microcapsules was analyzed 


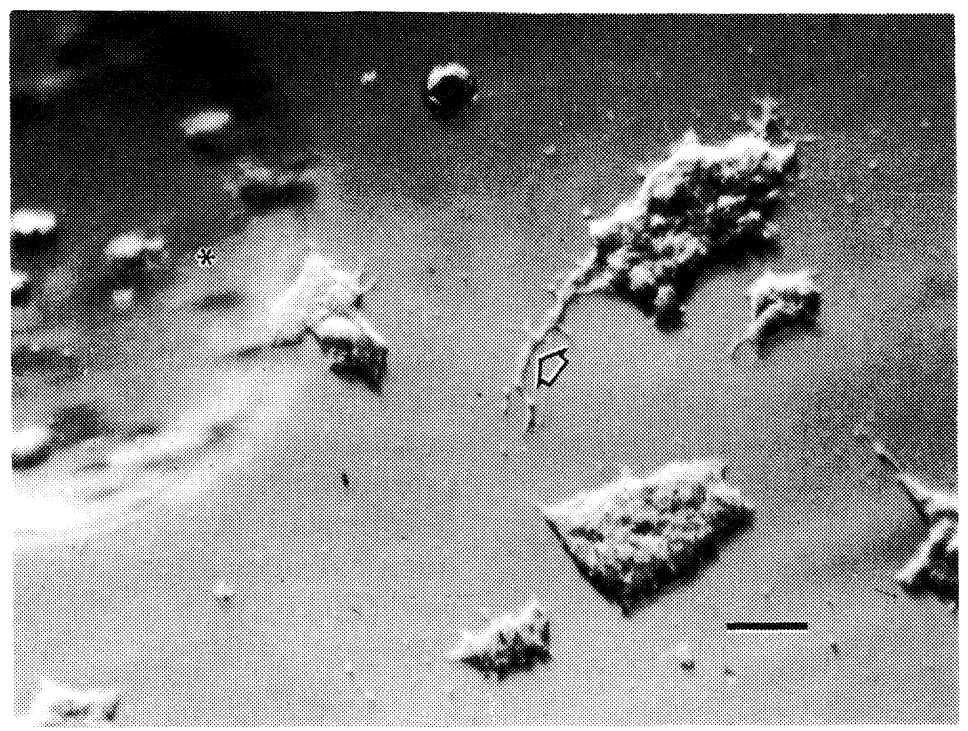

Fig. 1: Light micrograph of PC12 cells cocultured for 5 days in vitro with microcapsules containing the R208N.8 cell line as observed with Hofmann modulation optics. Note the neurites extending from the PC12 cells (arrow) indicating that the released NGF was bioactive. Note also the microcapsule, which can move during manipulations, containing the R208N.8 cells (*). Scale bar $=50 \mu \mathrm{m}$.

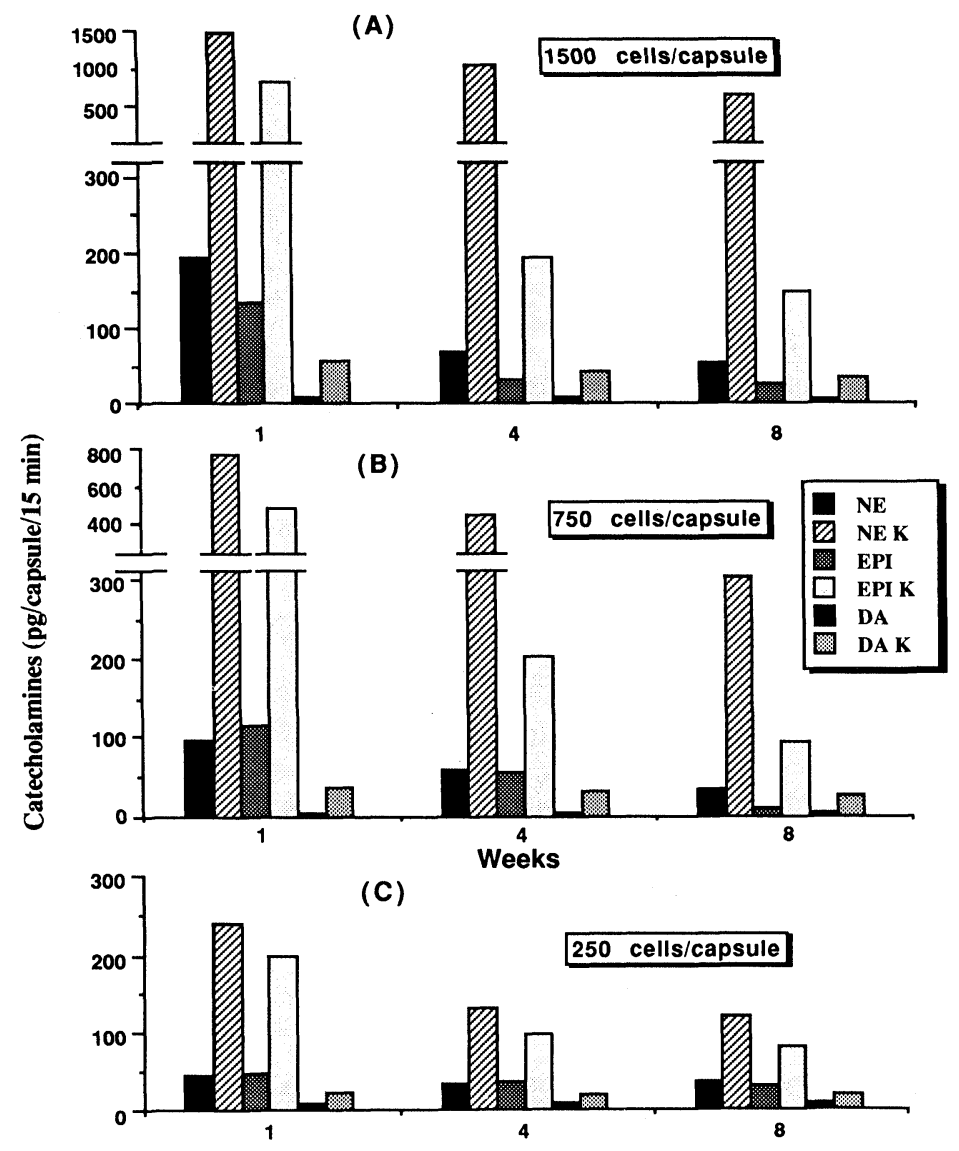

Fig. 2:

n vitro catecholamine release profiles at 1,4 and 8 weeks after 15 min incubations in HBSS with $5.4 \mathrm{mM}$ (basal) and $56 \mathrm{mM}$ (high $\mathrm{K}^{+}$) potassium of microcapsules containing high $(A)$, medium (B), and low (C) densities of BAC cells. Averages were determined by dividing the total catecholamines measured/well by the number of microcapsules/well at each given time (data presented as pg/capsule, with approximately 200 microcapsules in each of 3 wells). 

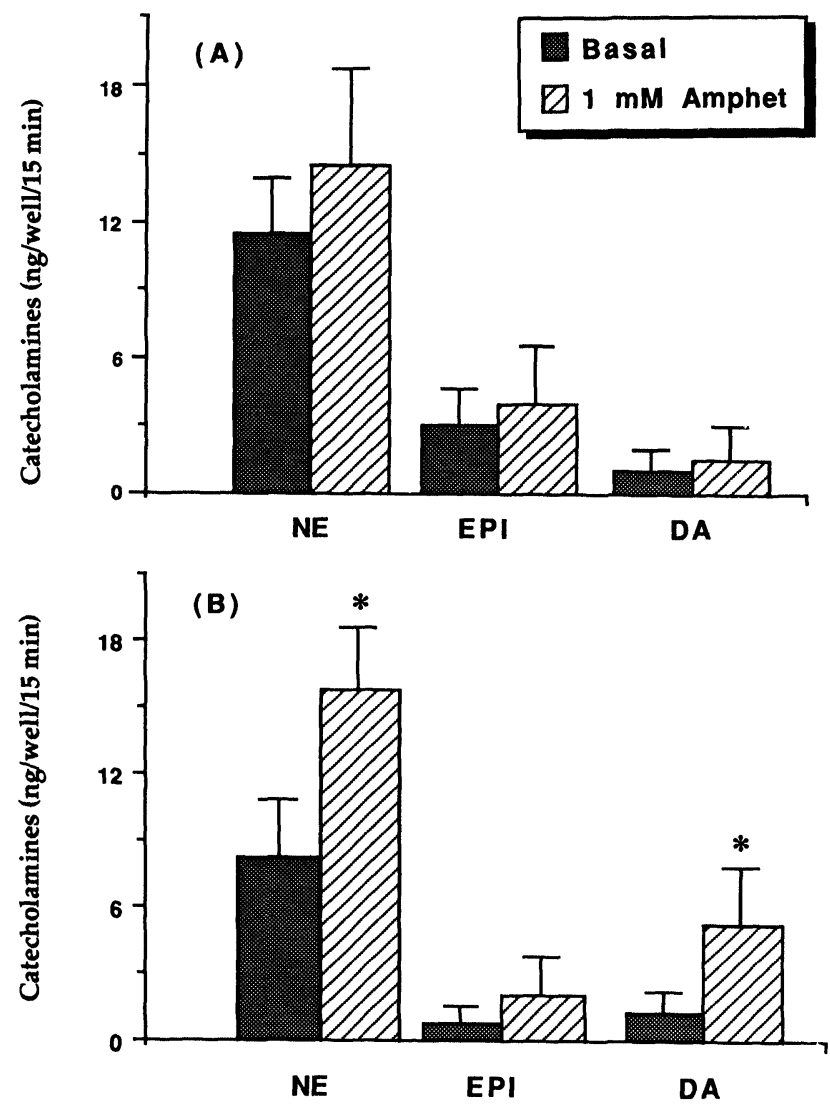

Fig. 3: Basal and $1 \mathrm{mM}$ amphetamine-induced release of catecholamines from $B A C$ containing mono- (A) and coseeded (B) microcapsules after 8 weeks in vitro. To compensate for the differences in BAC densities/capsule in each group, the release profiles were normalized for BAC cells by comparing 300 coseeded microcapsules/well to 200 monoseeded capsules/well. In the coseeded experiment, a statistically significant increase in NE and DA was observed after a $15 \mathrm{~min}$ exposure to amphetamine, as compared to basal quantities. *p<0.05 with Student's paired ttest. Bars represent means \pm S.E.M.

by double labeling with the fluorochrome markers FDA and PI. At both 4 and 8 weeks in vitro, only a few cells per cluster stained positive for PI (Fig. 5C). Generally, the distribution of non-viable versus viable cells showed a random dispersion. Ultrastructurally, intact and well preserved cinromaffin cells with their electrondense secretory vesicles were observed at 4 weeks (Fig. 5D), with few fibroblasts or endothelial cells surviving within the microcapsules. In the coseeded microcapsules, small neurites were observed at the light and electron microscopic level extending from the chromaffin cells by 4 weeks in vitro. In general, the chromaffin cells and fibroblastic cell line remained isolated from one another. The fibroblasts were observed to be in the vicinity of Matrigel $^{\otimes}$ within the capsule space. At the ultrastructural level, the chromaffin cells extended small neurites (Fig. 6A) and the fibroblasts continued to survive in the microcapsules after 12 weeks of maintenance in vitro (Fig. 6B).
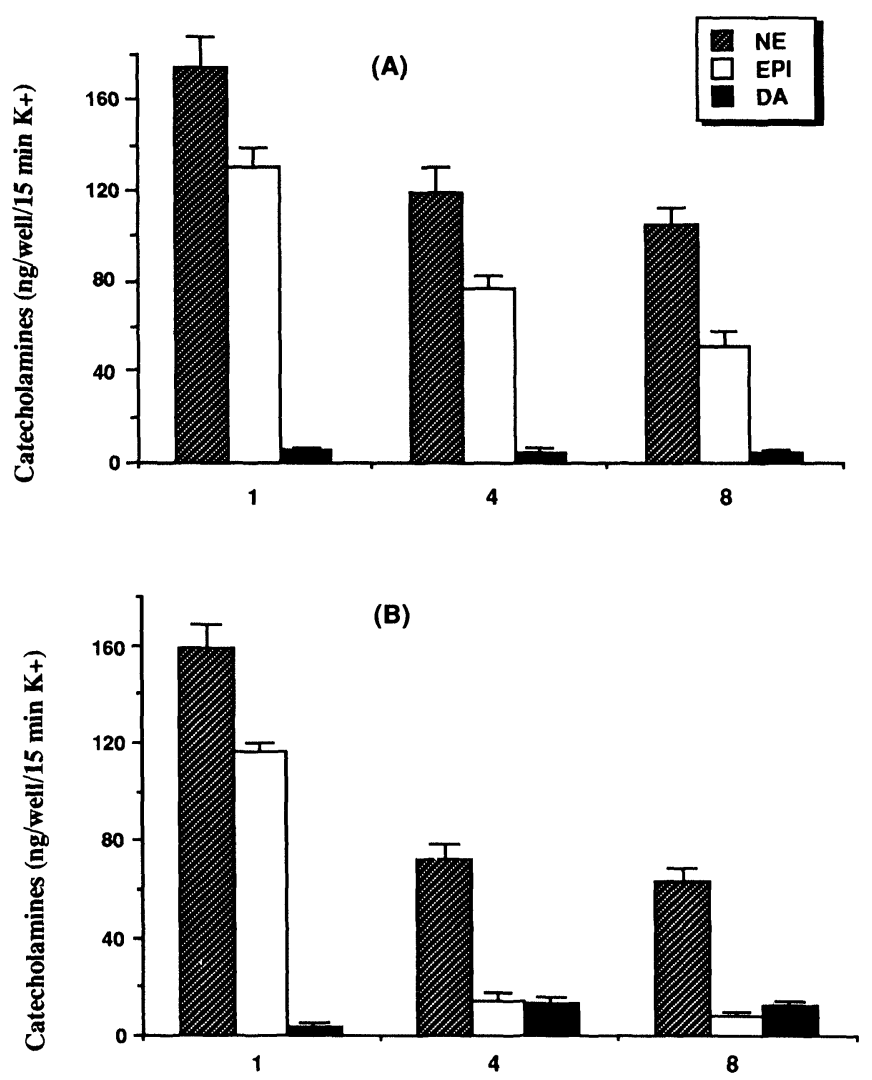

Fig. 4: The average potassium-evoked release of catecholamines after 1,4 and 8 weeks of maintenance in vitro comparing Matrige ${ }^{\otimes}$ containing chromaffin microcapsules, approximately 200 microcapsules/well (A), to approximately 300 coseeded microcapsules/well (B). The values are expressed as ng/well with bars representing means \pm S.E.M. 


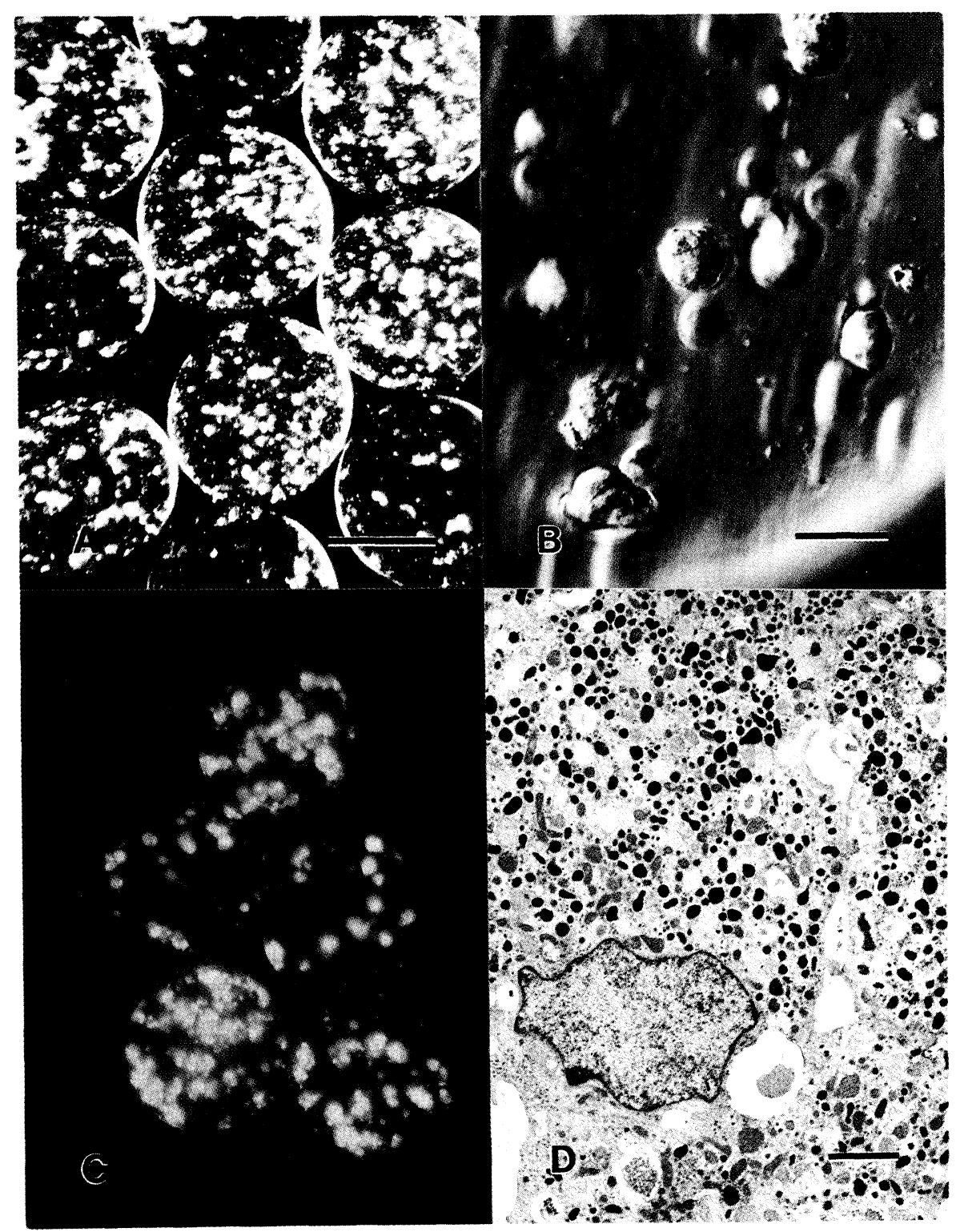

Fig. 5: A) Light micrograph of microcapsules containing BAC cells at the medium density taken with Hofmann modulation optics after the fabrication process. Scale bar $=300 \mu \mathrm{m}$. B) The BAC cells retain the rounded endocrine-like morphology and remain immobilized after an 8 week maintenance period in vitro. Scale bar = $50 \mu \mathrm{m}$. C) A double-labeled fluorescence technique shows the distribution of the viable FDA positive cells (green) to the non-viable PI positive (red) cells. D) An electron micrograph of microencapsulated chromaffin cells with their electron-dense storage granules after 4 weeks in vitro. Scale bar $=2 \mu \mathrm{m}$. 


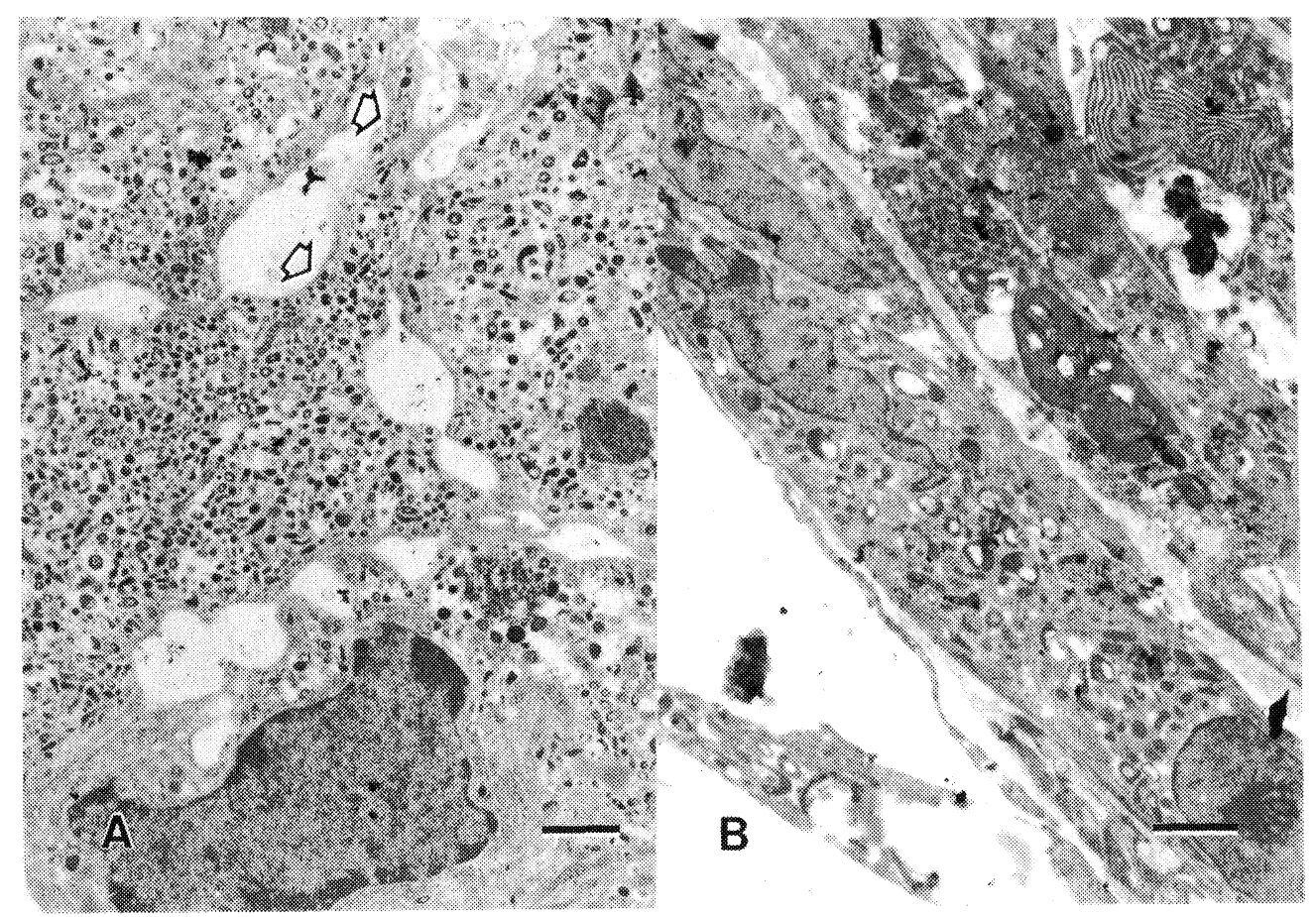

Fig. 6: A) An electron micrograph of a microcapsule containing chromaffin cells coseeded with the R208N.8 NGFsecreting fibroblast cell line after 12 weeks in vitro. Note the electron-dense secretory vesicles and neuritic outgrowths (arrows) from coseeded chromaffin cells. Scale bar $=1 \mu \mathrm{m}$. B) Electron micrograph of a coseeded microcapsule containing R208N.8 fibroblasts after 12 weeks of maintenance in vitro. Note the well preserved fibroblasts aligned along their long axis with their typical morphology. Scale bar $=1 \mu \mathrm{m}$.

\section{DISCUSSION}

The present study shows that dissociated BAC cells can be maintained for at least 12 weeks in culture when immobilized in partially crosslinked microcapsules previously shown to be selectively permeable. Since the small aggregates remained isolated from one another over time, viability was similar at the different densities analyzed. When larger cell aggregates, e.g., those greater than $100 \mu \mathrm{m}$ in diameter, are microencapsulated within polyelectrolytes, a significant degeneration of cells, i.e., greater than $50 \%$, is observed within a 2 week maintenance period in vitro (unpublished observations). Very few of the anchorage-dependent cells in the dissociated chromaffin cell suspension, the fibroblasts, endothelial and Schwann cells, were observed at the ultrastructural level, suggesting the alginate immobilization matrix may inhibit their proliferation. In contrast, the fibroblasts continue to proliferate to a confluent monolayer when the chromaffin cell suspension is grown on tissue culture flasks (plates) in vitro. Survival of the engineered fibroblasts in a microcapsular configuration required the addition of an extracellular matrix substrate.

The immobilized dissociated BAC clusters did not require the application of exogenous NGF for survival. Basal and potassium-evoked catecholamine release patterns were consistent between the groups over time. The output of EPI, especially in the high and medium density groups, dropped in greater proportions than NE or DA. This may be due to a reduction in phenylethanolamine-N-methyltransferase (PNMT) activity, which catalyzes the formation of epinephrine from norepinephrine, whose expression is controlled by the glucocorticoids of the adrenal cortex /33/. Within each group, an 
increase in catecholamine release was observed following a high $\mathrm{K}^{+}$incubation, showing that the chromaffin cells retained the capacity for exocytosis. The monoseeded chromaffin cells, irrespective of the presence of Matrigel ${ }^{\circledR}$, also retained their rounded endocrine phenotype, in contrast to the chromaffin cells coseeded with the NGF-secreting cells.

In the coseeding experiments, the Matrige ${ }^{\circledR}$ cell suspension was mixed with the alginate to provide a substrate for the anchorage-dependent NGF-secreting cells and support neuritic outgrowths from the chromaffin cells. Morphological observations revealed intact, viable fibroblasts in the microcapsules for up to 12 weeks in vitro, suggesting that the fibroblasts continue to survive. The ultrastructure of the coseeded chromaffin cells after 12 weeks in vitro together with the potassium-evoked catecholamine release profile at 4 and 8 weeks also suggests that the engineered fibroblasts retained the capacity to secrete bioactive NGF. Application of NGF to adrenal medulla cultures has been shown to elicit the selective induction of tyrosine hydroxylase and dopamine- $\beta$ hydroxylase $/ 16 /$, inducing a neuronal transformation, and altering the catecholamine profile. The activity of PNMT was down regulated in the coseeded microcapsules as shown by a dramatic decrease in EPI release. Further evidence of a shift towards a neuronal transformation was observed when the coseeded microcapsules were exposed to $1 \mathrm{mM}$ amphetamine after an 8 week maintenance period in vitro. A significant increase in measured quantities of $\mathrm{NE}$ and $\mathrm{DA}$ was observed as compared to the monoseeded capsules.

A previous study has revealed that intrastriatal implants of dissociated BAC cells in microcapsules consistently survived at 4 weeks and alleviated apomorphine-induced rotations in the 6-OHDA unilateral lesioned rat model /1/. These cells also appeared endocrine-like in their morphology /1/. Thus, in both cases exogenous NGF application did not appear to be required for short-term survival. Long-term survival may, however, require the addition of NGF.

Microencapsulation may provide a method for consistent chromaffin cell survival in intrastriatal transplants without exogenously applied NGF /1/. The results indicate that low concentrations of striatal NGF or the nutritional conditions cannot account for the poor survival of unencapsulated intrastriatal chromaffin cell implants. By modifying the internal milieu of the microcapsules, comparisons of striatal implants containing endocrine-like vs. differentiated chromaffin cells can be made, and thereby determine whether an altered phenotype survives better, and/or is more effective in ameliorating experimental parkinsonism.

\section{ACKNOWLEDGEMENTS}

We would like to thank Paula Weston and Armando P. Signore for their excellent technical help.

\section{REFERENCES}

1. Aebischer P, Tresco PA, Sagen J, Winn SR. Transplantation of microencapsulated bovine chromaffin cells reduces apomorphine-induced rotational symmetry in rats. Brain Res 1991; 560: 4349.

2. Bankiewicz KS, Plunkett RJ, Kopin IJ, Jacbowitz DM, London WT, Oldfield EH. Transient behavioral recovery in hemiparkinsonian primates after adrenal medullary allografts. Prog Brain Res 1988; 78: 543549.

3. Bing G, Notter MFD, Hansen JT, Gash DM. Comparison of adrenal medullary, carotid body and PC12 cell grafts in 6-OHDA lesioned rats. Brain Res Bull 1988; 20: 399-406.

4. Brown VJ, Dunnett SB. Comparison of adrenal and foetal nigral grafts on drug-induced rotation in rats with 6-OHDA lesions. Exp Brain Res 1989; 78: 214218.

5. Bohn MC, Cupit L, Marciano F, Gash DM. Adrenal medulla grafts enhance recovery of striatal dopaminergic fibers. Science 1987; 237: 913-916.

6. Freed WJ, Cannon-Spoor HE, Krauthamer E. Intrastriatal adrenal medulla grafts in rats. Long-term survival and behavioral effects. J Neurosurg 1986; 65: 664-670.

7. Freed WJ, Poltorak M, Becker JB. Intracerebral adrenal medulla grafts: a review. Exp Neurol 1990; 110: 139-166.

8. Goosen MFA, O'Shea GM, Gharapetian HM, Chou S, Sun AM. Optimization of microencapsulation parameters: semipermeable microcapsules as a bioartificial pancreas. Biotech Bioeng 1985; 27: 146150. 
9. Herrera-Marschitz M, Strömberg I, Olsson D, Ungerstedt U, Olson L. Adrenal medullary implants in the dopamine-denervated rat striatum. II. Acute behavior as a function of graft amount and location and its modulation by neuroleptics. Brain Res 1984; 297: 53-61.

10. Jones $\mathrm{KH}$, Senft JA. An improved method to determine cell viability by simultaneous staining with fluorescein diacetate-propidium iodide. J Histochem Cytochem 1985; 33: 77-79.

11. Korsching S, Auburger G, Heumann R, Scott J, Thoenen $H$. Levels of nerve growth factor and its mRNA in the central nervous system of the rat correlate with cholinergic innervation. EMBO J 1985; 4: 1389-1393.

12. Lim F, Sun AM. Microencapsulated islets as bioartificial endocrine pancreas. Science 1980; 210: 908-910.

13. Notter MFD, Hansen JT, Okawara S, Gash DM. Rodent and primate adrenal medullary cells in vitro: phenotypic plasticity in response to coculture with $\mathrm{C}_{6}$ glioma cells or NGF. Exp Brain Res 1989; 76: 38-46.

14. Olson L, Seiger A, Freedman R, Hoffer B. Chromaffin cells can innervate brain tissue: evidence from intraocular double grafts. Exp Neurol 1980; 70: 414-426.

15. Olson L, Strömberg I, Herrera-Marschitz M, Ungerstedt $U$, Ebendal T. Adrenal medullary tissue grafted to the dopamine-denervated rat striatum: histochemical and functional effects of additions of nerve growth factor. In: Björklund A, Stenevi U (Eds), Neuronal Grafting in the Mammalian CNS. Amsterdam: Elsevier, 1985; pp 508-518.

16. Otten U, Schwab M, Gagnon C, Thoenen H. Selective induction of tyrosine hydroxylase and dopamine $\beta$ hydroxylase by nerve growth factor: comparison between adrenal medulla and sympathetic ganglia. Brain Res 1978; 133: 291-303.

17. Patel-Vaidya U, Wells MR, Freed WJ. Survival of dissociated adrenal chromaffin cells of rat and monkey transplanted into rat brain. Cell Tissue Res 1985; 240: 281-285.

18. Pezzoli G, Fahn S, Dwork A, Truong DD, de Yebenes JG, Jackson-Lewis V, Herbert J, Cadet JL. Nonchromaffin tissue plus nerve growth factor reduces experimental parkinsonism in aged rats. Brain Res 1988; 459: 398-403.

19. Pollard HB, Pazoles C, Creutz CE, Scott JH, Zinder O, Hotchkiss A. An osmotic mechanism for exocytosis from dissociated chromaffin cells. J Biol Chem 1984; 259: 1114-22.

20. Sagen J, Pappas GD, Ortega JD. Host-graft relationships of isolated bovine chromaffin cells in rat periaqueductal grey. J Neurocyt 1990; 19: 697-707.

21. Short MP, Rosenberg MB, Ezzedine ZD, Gage FH, Friedmann T, Breakefield XO. Autocrine differentiation of $\mathrm{PC} 12$ cells mediated by retroviral vectors. Dev Neurosci 1990; 12: 34-45.

22. Strömberg I, Herrera-Marschitz M, Hultgren L, Ungerstedt $U$, Olson L. Adrenal medullary implants in the dopamine-denervated rat striatum. I. Acute catecholamine levels in grafts and host caudate as determined by HPLC-electrochemistry and fluorescence histochemical image analysis. Brain Res 1984; 297: 41-51.

23. Strömberg I, Herrera-Marschitz M, Ungerstedt U, Ebendal T, Olson L. Chronic implants of chromaffin tissue into the dopamine-denervated striatum. Effects of NGF on graft survival, fiber outgrowth and rotational behavior. Exp Brain Res 1985; 60: 335-349.

24. Strömberg I, Ebendal T, Seiger A, Olson L. Nerve fiber production by intraocular adrenal medullary grafts: stimulation by nerve growth factor or sympathetic denervation of the host iris. Cell Tissue Res 1985; 241: 241-249.

25. Tischler AS, DeLellis RA, Biales B, Nunnenmacher G, Carraba V, Wolfe HJ. Nerve growth factor-induced neurite outgrowth from normal human chromaffin cells. Lab Invest 1980; 43: 399-409.

26. Tresco PA, Winn SR, Jaeger CB, Greene LA, Aebischer P. Transplantation of polymer-encapsulated PC12 cells reduces lesion-induced rotational behavior. Submitted, 1991.

27. Unsicker K, Kirch B, Otten U, Thoenen H. Nerve growth factor-induced fiber outgrowth from isolated rat adrenal chromaffin cells: Impairment by glucocorticoids. Proc Natl Acad Sci USA 1978; 75: 3495-3502.

28. Unsicker K, Millar TJ, Hofmann HD. Nerve growth factor requirement of postnatal rat adrenal medullary cells in vitro for survival, aggregate formation and maintenance of extended neurites. Dev Neurosci 1982; 5: $412-417$.

29. Unsicker K, Vey J, Hofmann HD, Muller TH, Wilson AJ. C6 glioma cell-conditioned medium induces neurite outgrowth and survival of rat chromaffin cells in vitro: comparison with the effects of nerve growth factors. Proc Natl Acad Sci USA 1984; 81: 2242-2246.

30. Vahlsing HE, Varon S, Hagg T, Fass-Holmes B, Dekker A, Manley M, Mansthorpe M. An improved device for continuous intraventricular infusions prevents the introduction of pump-derived toxins and increases the effectiveness of NGF treatments. Exp Neurol 1989; 105: 233-243.

31. Winn SR, Aebischer P, Galletti P. Brain tissue reaction to permselective polymer capsules. J Biomed Mat Res 1989; 23: 31-44.

32. Winn SR, Tresco PA, Zielinski B, Greene LA, Jaeger $\mathrm{CB}$, Aebischer P. Behavioral recovery following intrastriatal implantation of microencapsulated $\mathrm{PC12}$ cells. Exp Neurol 1991; 113: 322-329.

33. Wurtman RJ, Pohorecky LA, Baliga BS. Adrenocortical control of the biosynthesis of epinephrine and proteins in the adrenal medulla. Pharmacol Rev 1972; 24: 411-426. 

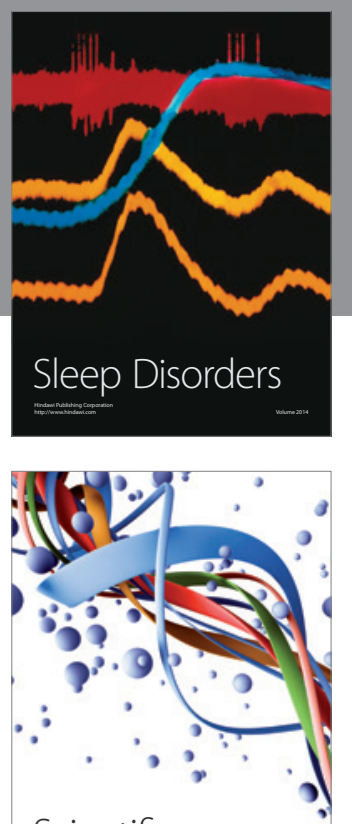

Scientifica
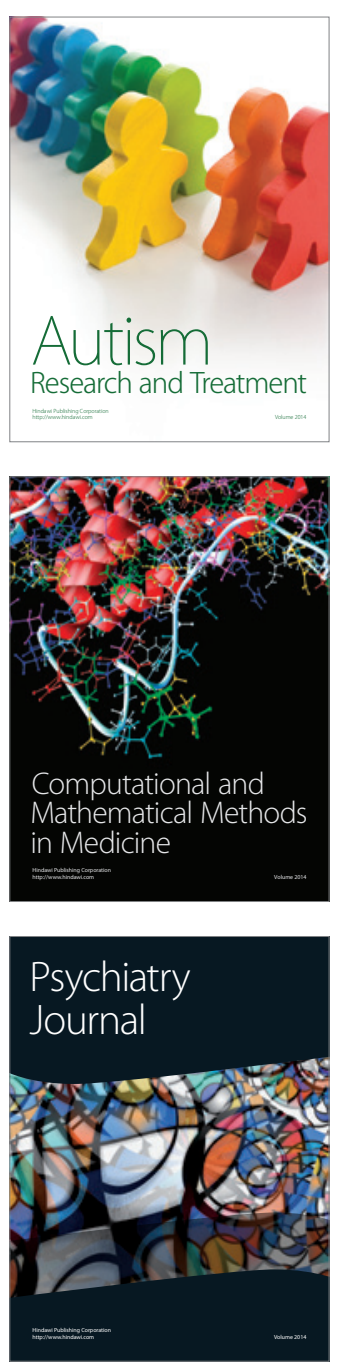
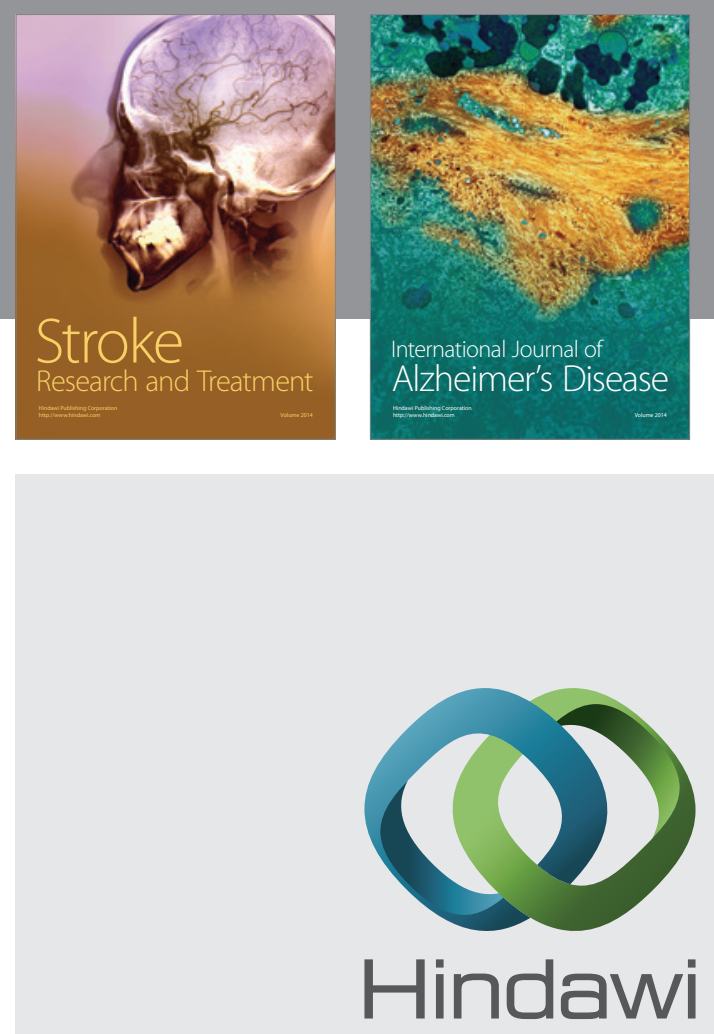

Submit your manuscripts at

http://www.hindawi.com
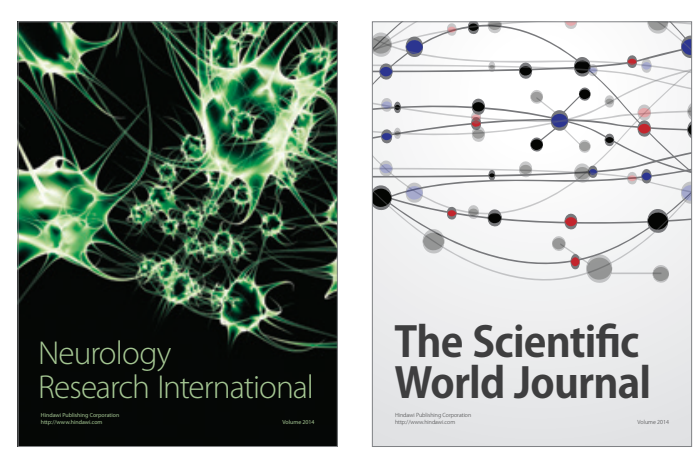

The Scientific World Journal

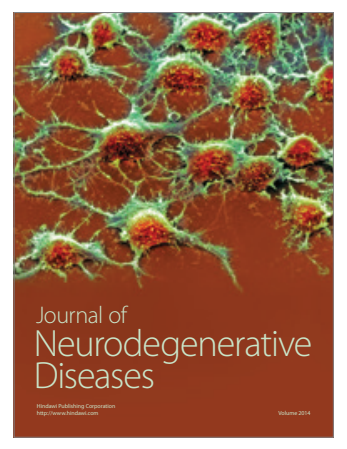

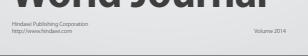

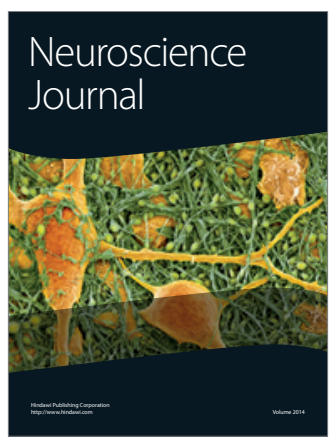

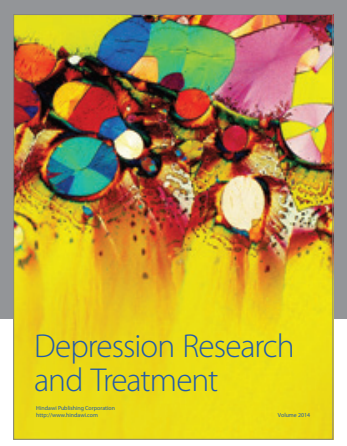
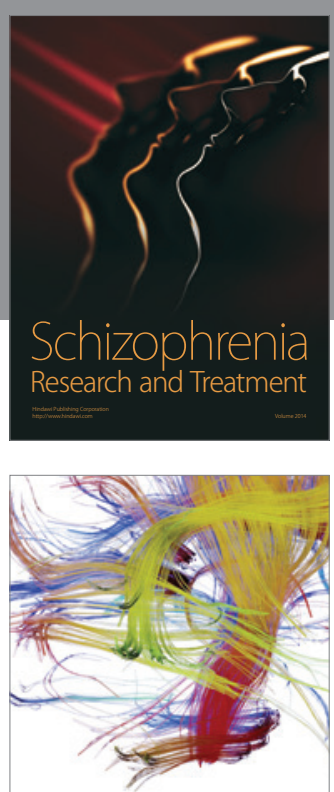

Brain Science

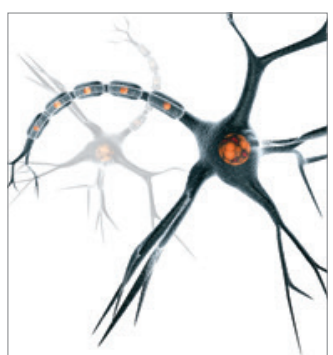

Neural Plasticity
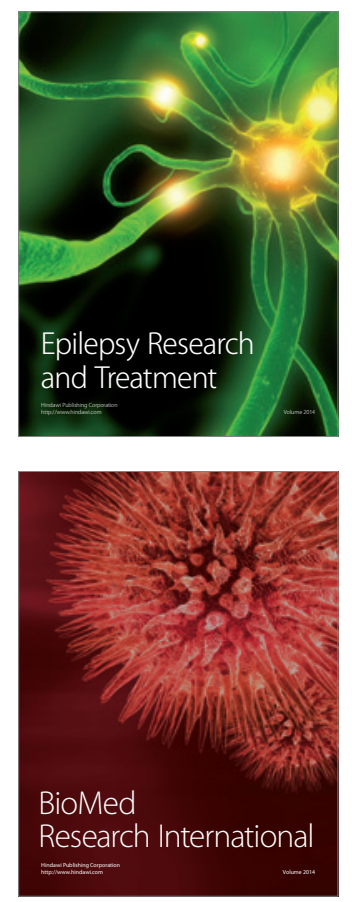

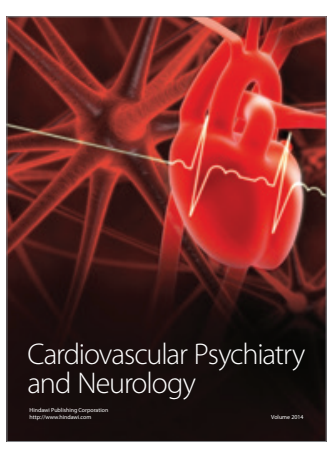

Parkinson's

Disease
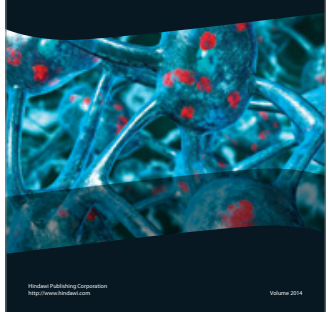